\title{
IMPLEMENTASI PENDIDIKAN INFORMAL HINDU DALAM MENJAGA POLA KOMUNIKASI REMAJA PADA PERGAULAN SEHARI-HARI
}

\author{
I Ketut Sudarsana \\ Institut Hindu Dharma Negeri Denpasar \\ iketutsudarsana@ihdn.ac.id
}

\begin{abstract}
The development of adolescents today is very worrying, especially teenagers is the next generation for Hindus in particular and also shoots for the nation of Indonesia. In order to avoid that association does not occur among adolescents, parents must be able to control and nurture their children. Parents can provide knowledge about the teachings of Hinduism and can always maintain communication with adolescents. Adolescents are not wrong association and also to not fall into the negative direction that can harm the child with parents especially in the era of globalization as nowadays all sophisticated. In addition to teachers in schools, and the environment of residence for teenagers. Parents who play the most important role here so that teenagers are not wrong association in this day and age. Parents must also be able to provide understanding and pengertiaan about the teachings of Hinduism, but the teachings of Hinduism is not only to be understood and understood but also must be biased and practiced directly with all my heart in order to find happiness inwardly.
\end{abstract}

Keywords: Hindu Informal Education, Communication Pattern of Youth

\section{ABSTRAK}

Perkembangan anak remaja saat ini sangat mengkhawatirkan, apalagi remaja adalah generasi penerus bagi umat Hindu pada khususnya dan juga tunas bagi bangsa Indonesia. Agar salah pergaulan itu tidak terjadi pada kalangan remaja maka orang tua harus dapat mengontrol dan membina anaknya. Para orang tua dapat memberikan pengetahuan tentang ajaran-ajaran agama Hindu dan bisa selalu menjaga komunikasi dengan remaja. Remaja tidak salah pergaulan dan juga agar tidak terjerumus ke arah yang negatip yang dapat merugikan anak dengan orang tua apalagi di era globalisasi seperti saat ini semua serba canggih. Selain guru di sekolah, dan lingkungan tempat tinggal bagi remaja. Orang tualah yang memegang peranan paling penting disini agar remaja tidak salah pergaulan di jaman sekarang ini. Orang tuajuga harus dapat memberikan pemahaman dan pengertiaan tentang ajaran agama Hindu, tapi ajaran agama Hindu bukan hanya untuk dipahami dan dimengerti saja tapi juga harus di hayati dan dipraktekan langsung dengan sepenuh hati supaya menemukan kebahagiaan secara lahir batin.

Kata Kunci : Pendidikan Informal Hindu, Pola Komunikasi Remaja

\section{PENDAHULUAN}

Perkembangan ilmu pengetahuan dan teknologi sangat pesat mempengaruhi masyarakat termasuk anak-anak remaja, sebab anak-anak remaja mempunyai rasa ingin tahu dan mencoba yang sangat besar. Peranan orang tua sangat dibutuhkan untuk mendidik anak agar tidak terjerat dalam pergaulan bebas masa kini dan Pendidikan informal Hindu yang bisa memberikan rasa aman, dan damai sejahtera, 
maka peranan agama disini sangat di perlukan, sesuai dengan sloka yang terdapat dalam ajaran Veda yang berbunyi : "Atmanam moksartham jagadthita ya ca iti dharma” Artinya: Bahwa agama atau dharma bertujuan untuk membina kehidupan yang sejahtera dan bahagia secara lahir batin. ( Kardiani,2004:1)

Kutipan pustaka suci di atas mempunyai makna, ajaran agama tidak hanya dapat dimengerti dan dipahami saja oleh setiap orang yang ingin menjalani hidup dengan damai. Tapi dilaksanakan dan diamalkan oleh setiap anggota Pendidikan informal Hindu agar dapat mempraktekkan secara langsung, dengan demikian Pendidikan informal Hindu bisa mejalankan kehidupan yang damai dan sejahtera yang dilandasi oleh ajaran agama Hindu juga dapat merubah tingkah laku dan pergaulan pada setiap remaja pada era globalisasi.

Pendidikan informal Hindu adalah bentuk kehidupan bersama yang merupakan lembaga sosial terkecil dan terpenting. Pendidikan informal Hindu pada hakikatnya adalah lembaga pendidikan agama Hindu yang pertama dan utama sehingga merupakan lembaga yang dapat menumbuhkan terjalinnya pengabdian dan teraturnya peningkatan hidup dalam mencapai tujuan hidupnya. (Wiana, 1997:43)

Pendidikan informal Hindu adalah tempat untuk belajar dari tidak tahu menjadi tahu, tidak bisa menjadi bisa dan juga untuk menghadapi masalah yang akan dijumpai masyarakat umum. Pengetahuan dapat diperoleh dalam Pendidikan informal Hindu dan pendidik yang diberikan oleh orang tua sehingga bisa melakukan sesuatu yang diinginkan sesuai ajaran agama yang telah diberikan oleh orang tua.

Orang tua mempunyai peranan yang sangat penting didalam pendidikan informal Hindu untuk seorang anak, baik dalam menjaga keharmonisan maupun dalam memberikan pendidikan tentang agama Hindu serta menjaga terjalinnya komunikasi yang baik, teratur dan terarah terhadap anak. Orang tua adalah seseorang yang dapat mempengaruhi watak dan sifat dari anak itu sendiri. Orang tua memelihara dan menjaga buah hatinya mulai dari bayi hingga anak itu beranjak dewasa sampai mereka mampu untuk membina kehidupannya sendiri.

Tahap remaja sangat rentan terhadap pengaruh-pengaruh, baik dalam lingkungan keluarga itu sendiri maupun di dalam lingkungan tempatnya tinggal. Karena masa remaja sering disebut sebagai masa peralihan dari anak-anak menuju masa kedewasaan. Peranan orang tua sangat diperlukan untuk membentuk suatu karakter atau sifat dan budi pekerti yang luhur. Pentingnya pendidikan agama Hindu khususnya bagi remaja sangat positif untuk perkembangan budi pekerti dan kepribadian anak remaja jaman sekarang. Memberikan pengetahuan agama Hindu sejak usia dini sangatlah berpengaruh terhadap kepribadian anak remaja. Orang tua harus dapat meluangkan waktunya dengan anak remaja untuk melakukan komunikasi. Melalui komunikasi remaja akan bisa memahami dan menghayati sesuatu yang telah dibicarakan dengan orang tuanya, agar anak remaja tidak 
salah bergaul dan tidak terjerumus kearah pergaulan bebas yang bersifat negatif, maka orang tua dengan anak remaja perlu melakukan komunikasi.

Komunikasi yang perlu dilakukan dan diperhatikan dalam situasi komunikasi tatap muka adalah bersikaplah empatik dan simpatik. Tunjukkanlah sebagai komunikator yang terpercaya, bertindaklah sebagai pembimbing bukan sebagai pendorong, berbicara dengan gaya mengajak, bukan menyuruh, bercakaplah secara meyakinkan, kemukakan fakta dan kebenaran, jangan bersikap super, jangan mengeritik, jangan emosian dan jangan mengatakan hal-hal yang mengawatirkan. (Ceteg Rurung, 2003, 20).

Melakukan komunikasi dengan anak remaja dijaman sakarang membuatnya merasakan senang, santai dan nyaman sehingga anak-anak akan mau mendengarkan orang tua berbicara. Sebaliknya orang tua jika melakukan komunikasi yang dilandasi dengan emosi, marah-marah, selalu menyalahkan anak tersebut dengan melempar kesalahannya sendiri kepada anak-anak, dan sering berbohong maka anak merasa tidak senang dan tidak menghargai orang tuanya. Anak tidak akan peduli lagi dengan nasehat dari orang tuanya sendiri dan mengakibatkan komunikasi yang berlangsung tidak baik. Anak remaja sendiri merasa dan menjadi jauh dengan orang tuanya.

Orang tua sangat sayang kepada anaknya, akan memberikan seluruh kasih sayangnya kepada anaknya karena bagi mereka anak adalah segala-galanya. Anak adalah anugrah yang terindah yang pernah dimiliki oleh sepasang orang tua. Anak adalah hasil buah cinta dari sepasang orang tua. Orang tua akan memberikan seluruh hidupnya hanya untuk anaknya. Karena rasa sayang yang berlebihan orang tua kepada anaknya dan orang tua yang ingin memberikan segalanya kepada anaknya. Orang tua kadang melupakan bagaimana cara mendidik anak dengan baik dan benar yang sesuai dengan ajaran agama Hindu. Sayang orang tua kepada anak dan orang tua sibuk dengan pekerjaannya masing-masing, jadi orang tua tidak memikir dampak negatifnya dalam pergaulan. Anak akan mendapatkan pergaulan bebas tanpa dikontrol dari orang tua, dan juga karena apa yang di inginkan terus dikabulkan oleh orang tua. Suatu saat nanti kalau orang tua mereka tidak mampu untuk memenuhi yang diinginkan anaknya maka akan muncul pikiran yang negatif karena orang tuanya tidak bisa memenuhi keinginan tersebut.

Remaja suka melakukan sesuatu yang diinginkannya. Namun kalau tidak di turuti oleh orang tua pasti akan berontak dan melakukan tindakan yang membuat orang tuanya takut dan cemas. Mengancam orang tua dengan tindakan yang dapat membahayakan orang tua maupun dengan diri anak itu sendiri. Saking sayangnya orang tua dengan anaknya apalagi anak semata wayangnya. Dengan ancaman seperti itu akhirnya orang tua pun menurut dengan anak dan mengabulkan semua keinginan anaknya, agar anak tidak melakukan perbuatan yang bersifat negatif.

Berkaitan dengan pergaulan zaman sekarang, dapat dilihat kejadian atau kelakuan 
remaja jaman sekarang. Minum-minuman keras sampai mabuk setelahnya membuat masalah dengan orang lain sehingga terjadi tawuran, dan sebagaian besar dari anak remaja zaman sekarang pun sudah ada yang melakukan seks bebas diluar nikah tanpa melihat resikonya, dan yang menyedihkan lagi sampai-sampai mereka terjerat narkoba. Selain para guru di sekolah, orang tua juga harus memperhatikan anaknya dengan cara menjaga komunikasi dan memberikan ajaranajaran agama khususnya Agama Hindu agar remaja-remaja sekarang berada dijalan yang benar.

\section{PEMBAHASAN}

Manusia di dunia ini tidak bisa hidup sendiri karena manusia adalah mahluk sosial yang saling membutuhkan antara manusia satu dengan manusia lainnya. Karena dari itu sesama manusia harus saling menghormati dan menghargai untuk menjadi hidup yang lebih damai, tentram, sejatera. Manusia tidak bisa lepas dari berkomuniksi setiap hari melakukan komunikasi baik dengan cara berbicara atau dengan komunikasi gerak tubuh (Artana, 2010)

Melakukan komunikasi agar tahu perkembangan dan sesuatu yang terjadi di sekitar lingkungan tempat tinggalnya, komunikasi dapat dilakukan dimana saja. Dalam hal ini komunikasi sebagai alat untuk melakukan pembinaan atau pendidikan untuk anak remaja agama Hindu agar terarah ke hal-hal yang baik dan tidak terjerumus kearah yang bisa menyebabkan masa depan anak itu suram, serta dapat membuat diri anak itu mempunyai arah untuk meraih masa depan yang lebih baik. Adapun peranan orang tua dalam melakukan komunikasi dengan anak anak remaja dengan cara, ngobrol dengan anaknya, memberikan nasehat kepada anak, berbagi pengalaman dengan anak, dan menganggap anak sebagai teman. Untuk mempermudah penulisan karya tulis ini maka penulis membaginya dengan empat sub bahasan yaitu:

\section{Jenis atau Bentuk Komunikasi Dalam Keluarga}

Jenis atau bentuk komunikasi dalam keluarga adalah orang tua sering melakukan bincang-bincang dengan anak dan orang tua memberikan nasehat kepada anak. Dengan cara melakukan komunikasi antar pribadi atau tatap muka antara orang tua dengan anak. Komunikasi seperti ini sangat penting untuk menjalain hubungan yang harmonis antara orang tua dengan anak, sudah barang tentu dalam hal ini adalah untuk menjalin hubungan yang harmonis dalam keluarga. Melakukan komunikasi yang baik agar anak dapat terarah kejalan yang benar supaya anak tidak melakukan tindakan yang dapat merugikan dirinya sendiri.

\section{a. Orang Tua Sering Melakukan Bincang-Bincang Dengan Anak}

Orang tua menyempatkan waktu kepada anaknya untuk dapat berbincangbincang. Sambil memberikan pendidikan terhadap anak remajanya dengan maksud agar komunikasi dengan anak tidak terputus, perlu kiranya orang tua memahami cara berkomunikasi yang efektif dengan 
anaknya, antara lain:

1) Membuka pintu, yaitu ungkapan orang tua yang memungkinkan anak untuk membicarakan lebih banyak, mendorong anak untuk mendekat dan mencurahkan isi hatinya. Dan yang penting menumbuhkan pada anak rasa diterima dan dihargai. Beberapa pernyataan yang bersifat membuka antara lain: "Saya mengerti "Ya hmm "Oh ya" Coba ceritakan lebih banyak "ibu kok tertarik ya" Kelihatannya kamu seneng ya

2) Komunikasi dengan empatik, prinsip Komunikasi Empatik: "Berusaha mengerti lebih dahulu, baru dimengerti" Dalam mendengarkan empatik, sebagai orang tua berusaha masuk ke dalam kerangka pikiran atau memahami perasaan anak remaja. Sebagai orang tua, tidak hanya mendengar dengan telinga, tapi dengan mata dan hati. Hati yang merasakan, memahami dan menyelami dengan permasalahan yang sedang dialami oleh anak remaja. Mata orang tua yang mengamati pesan-pesan yang diekspresikan oleh anak.

Orang tua menggunakan otak kanan sekaligus otak kiri. Mendengar Empatik adalah mendengar untuk mengerti baik secara emosional sekaligus intelektual, bukan dengan maksud untuk menjawab. Orang tua harus mengendalikan sifat emosional kepada anaknya agar anak lebih nyaman di dalam mengobrol dan tidak terjadi ketegangan yang dapat membuat anak itu kesal.

Memang tidak mudah untuk dapat menjalin komunikasi yang baik dengan anak remaja yang sedang mengalami berbagai gejolak dalam dirinya. Tetapi tidak berarti tidak bisa melakukan komunikasi. Pemahaman dan pengertian sebagai orang tua atas kesulitan-kesulitan yang sedang dialami anak remaja merupakan hal yang sangat penting bagi orang tua maka anak remaja membutuhkan pengertian dari orang tuanya bahwa anak sedang mengalami proses perubahan sikap seperti ini akan sangat mendukung terjalinnya komunikasi yang baik dengan anak remaja.

\section{b. Orang Tua Memberikan Nasehat Kepada Anak Remaja}

Orang tua menasehati anaknya dengan cara bahasa yang membuat anak itu senang dan tertarik untuk mendengar nasehat orang tua selanjutnya. Orang tua menasehati anaknya dan berpesan kepada anak baik-baik diluar rumah. Sebelum anak keluar rumah orang tua berpesan atau menahsehati dengan bahasa dan kata yang sopan agar anak mau mendengar pesan orang tua. Supaya anak tidak melakukan hal yang merugikan dirinya sendiri. Seorang anak tentu kadang kala berbuat sesuatu yang tidak sesuai dengan pandangan orang tuanya. Bilamana perbuatannya itu sering dilakukan, maka 
anak tersebut dikatakan sebagai anak nakal maka disni lah peran orang tua untuk menasehati anaknya tersebut agar anak itu tidak melakukan perbuatan yang salah berulang-ulang supaya anak tidak juga merasa selalu disalahkan. (Berata, 2010)

Sebagai seorang anak yang alam pikirannya masih belum sangat berkembang dan belum mempunyai wawasan luas, karena anak remaja masih mencari jati diri dan mempunyai sifat masih ingin mencoba-coba, tentunya sering mendapatkan teguran dari orang tuanya. Teguran itu sebenarnya nasehat untuk anak. Terlebih-lebih seorang anak yang nakal tentu akan mendapatkan hukuman dari orang tua, semua itu dilakukan orang tua karena kebandalan anak, orang tua memberikan hukuman agar anak kapok dan anak tahu apa yang dilakukan itu anak salah. Semua orang tumbuh dari bayi, lalu menjadi anak kecil, dan hingga sekarang ini. Sewaktu sebagai seorang anak yang mempunyai orang tua, tentu pernah mengalami teguran oleh orang tua. Walaupun kadang kala bagi anak tersebut merasa bahwa perbuatannya tidak salah, tetapi orang tuanya melarangnya bahkan sampai menghukumnya. Orang tua melakukan itu kerana orang tua tidak mau melihat anaknya salah dalam pergaulan dan orang tua berharap anaknya menjadi lebih baik dari diri orang tua tersebut. Karena sering dihukum oleh orang tua anak itu ingin berontak karena kesal, tetapi apa daya karena takut dihukum lebih berat lagi sungguh suatu keadaan yang menyedihkan bagi diri anak.

Dirinya merasa akan mendapatkan kesenangan dengan melakukan perbuatannya, tetapi akhirnya hukuman menyakitkan yang didapatnya. Maka janganlah menjadi anak yang nakal dan berani dengan orang tua. Orang tua seharusnya dihormati seperti ajaran agama Hindu di dalam Catur Guru seperti dalam ajaran agama Hindu yaitu tentang Catur Guru merupakan empat guru yang patu dihormati. Dimana bagian dari Catur Guru adalah sebagai berikut:

a. Guru rupaka/reka adalah orang tua kan-dung dirumah yang memberikan pendidikan, makanan, pakaian, dan kebutuhan lain-lainnya

b. Guru pengajian adalah guru yang mengajar di sekolah yang memberikan pendidikan ilmu pengetahuan

c. Guru wisesa adalah pemerintahan

d. Guru Swadhyaya adalah Tuhan Yang Maha Esa

Seorang anak harus dapat menerima nasehat dari orang tua, bahwa dirinya dihukum demi kebaikannya sendiri, tetapi sebenarnya dirinya tidak tahu apakah yang dilakukan sudah baik bagi dirinya karena anak remaja itu merasa dan mengaggap dirinya sudah paling benar. Tapi yang diketahui oleh anak remaja bahwa orang tua hanya melarang untuk melakukan lagi perbuatan yang menyenangkan dirinya, anak tidak menyadari resiko yang akan terjadi asalkan anak itu merasa senang 
anak akan lakukan hal tersebut. Sehingga orang tua menasehati berkali-kali tidak juga di hiraukan oleh anak dan terpaksa anak dihukum agar anak menyadari kesalahanya. Inilah suatu proses belajar dan mengajar yang umum berlangsung sejak lampau hingga sekarang.

Anak merasakan kebingung, benci, kesal dan takut bercampur aduk dipikirannya. Dirinya merasa ketidak adilan sebagai anak yang tidak dapat melakukan apa yang disukainya, sedangkan orang tua dapat melakukan apa saja tanpa ada yang melarang. Perlu kiranya orang tua memahami alam pikiran anak remaja, walaupun mereka kadang kala tidak mengetahui akibat dari perbuatannya karena rasa egois anak remaja yang sangat besar, tetapi apa yang terbaik menurut pandangan mereka belum tentu yang terbaik bagi orang tua. Orang tua sudah mempunyai pengalaman dan pengetahuan yang lebih luas, sehingga mereka mengetahui kekeliruan pandangan dari para anaknya.

Sadarkah para orang tua bahwa ada suatu berkah yang sangat luar biasa bagi seluruh orang tua. Dimana seorang anak, walaupun sering kali mendapat hukuman. Anak itu dapat melupakannya. Bayangkan bilamana setiap orang masih mengingat segala hukuman yang diterimanya sewaktu kecil. Bila mereka tidak melupakannya, tentu semua orang akan ingat berapa banyak ayah, ibu mereka telah menghukum mereka. Sangat sedikit sekali kejadian yang dapat diingatnya dan tersimpan dihatinya, bila tidak tentu semua orang akan dendam terhadap orang tua.

Bersyukurlah para orang tua bahwa anak-anak tidak dipengaruhi oleh ikatan pikiran yang kuat, sehingga segalanya dapat diterima dan terlupakan. Bila anak menghukum orang tua walau hanya sekali saja maka anak itu di sebut anak durhaka, Manusia kerap kali mengingkari Yang Maha Kuasa, tetapi sungguh suatu berkah bagi para mahluk bahwa Yang Maha Penciptaa selalu melimpahkan cinta kasih yang tanpa batas kepada manusia tiada hentinya.

\section{Makna Komunikasi Dalam Pendidikan Informal Hindu}

Manusia setiap hari melakukan komunikasi hampir setiap detik, dimana komunikasi memiliki tujuan agar manusia mendapatkan informasi atau berita dari orang lain agar tidak ketingalan informasi maka itu manusia perlu melakukan komunikasi. Untuk mempersempit permasalah dalam penelitian ini penulis mengarahkan ke arah makna komunikasi antara orang tua dengan anak.

Komunikasi yang dilakukan oleh orang tua dengan anak remaja bertujuan, agar anak tidak salah dalam pergaulan dan membentuk sikap dan tingkah laku anak remaja agar menjadi anak yang suputra dan berguna bagi keluarga dan masyarakat. Komunikasi tatap muka dengan cara ngobrolngbrol dan memberikan nasehat kepada anak sangat penting sekali dalam membina dan 
memelihara kepribadian anak remaja dan juga dapat menjalin hubungan yang akrab antara orang tua dengan anak untuk tercapainya rasa kekeluargaan di dalam hidup berumah tangga.

Proses komunikasi semacem itu dapat diulangi kembali dalam siklus yang positif. Artinya proses komunikasi yang selalu dapat mengarakan atau dilakukan tindakan sebagai yang diharapkan, maka menurut (Harmoko, 1988:70-71) perlu diperhatikan

a. Konsistensi dari isi peran komunikasi serta penyampainnya, agar versi yang diproyeksikan dalam proses komunikasi akan lebih mudah diserap oleh anak tersebut.

b. Waktu penyampaian pesan-pesan dalam berkomunkasi perlu diatur sedemikian hingga agar tidak menggangu kegiatan rutin anak.

c. Pemilihan topik yang akan disajikan kepada anak oleh orang tua, dimana yang memang penting dalam sewaktu-waktu. Dalam hal ini orang tua lebih berperan dalam menetapkan topik yang memang perlu untuk diketahui dan dilaksanakan oleh anak.

Bertitik tolak dari hal tersebut diatas. sekali pun suatu proses komunikasi telah berhasil mengadakan perubahan atas sikap dan tingkah laku sesuai dengan yang dikehendaki, hal ini masih perlu disesuaikan dengan tindak lanjut berupa penguatan agar untuk kedepan bisa tetap di lanjutkan lagi dan dikembangkan menjadi lebih baik dari sekarang dalam menjalin komunikasi.

\section{Peranan Orang Tua Dalam Komunikasi}

Orang tua dalam melakukan komunikasi memiliki peran yang sangat penting. Saat melakukan komunikasi dengan seorang anak remaja sebaiknya orang tua menunjuk diri sebagai komunikator yang bisa dipercaya dan orang tua bertindak sebagai pembimbing bukan sebagai pendorong. Adapun cara orang tua dengan berbagi pengalaman dengan anaknya dan juga orang tua menganggap anak sebagai teman supaya komunikasi yang dilakukan berjalan dengan baik.

\section{a. Orang Tua Berbagi Pengalaman Dengan Anak Remaja}

Orang tua berbagi pengalaman dengan anak remajanya dimana cara ini untuk mendekatkan diri dengan anak agar selalu bisa mengontrol anak remaja mereka. Anak sudah beranjak remaja dimana anak pada usia 16 keatas perlunya bimbingan dari orang tua. Memberikan pengalaman yang sudah pernah orang tua alami agar anak tidak salah memilih jalan hidupnya kedepan dan anak remaja tahu apa yang harus dilakukan dengan pengalaman yang di berikan oleh orang tua.

Bahasa asli remaja disebut adolescence, yang berasal dari bahasa latin adolescene berarti "tumbuhan dengan kematangan". Bahasa primitif dan orang purbakala memandang masa puber serta masa remaja tidak jauh berbeda didalam kehidupannya. Anak-anak menuju masa kedewasaan setelah dapat melakukan repro-duksi. Masa keremajaan bagi wanita 
berlangsung antara usia 12 tahun sampai dengan usia 21 tahun, dan bagi seorang pria antara usia 13 sampai dengan 23 tahun, rentang usia remaja ini dapat dibagi lagi menjadi dua, yaitu: 1) usia dari 12 atau dari usia 13 tahun sampai dengan usia 17 atau 18 tahun yang sering disebut dengan usia remaja awal; 2) sedangkan usia 17 atau 18 tahun sampai dengan usia 21 atau usia 23 tahun yaitu adalah usia remaja akhir (Ali, 2004 : 9).

Kalangan pada anak-anak remaja, kegiatan bercerita merupakan suatu hal yang sangat digemari dan dinantinanti. Anak akan mulai tertawa sambil terpingkal-pingkal tatkala kisah lucu mulai diceritakan. Begitupun sebaliknya, anak pun akan ikut hanyut dalam kesedihan ketika ia mendengarkan cerita sedih.

Berceritalah kepada anak tentang kisah yang menggambarkan tokoh yang berbudi baik dan sikap-sikap terpuji lainnya yang ingin orang tua tanamkan kepadanya. Gunakan bahasa sederhana dan mudah dicerna oleh anak remaja. Dengan demikian, cerita yang didengarkan oleh anak remaja dapat meresap ke dalam hati dan perasaannya. anak pun akan dengan mudah menerapkan perilaku baik yang ada dalam cerita tersebut ke dalam kehidupan nyatanya. (Lastra, 2010)

Perlu diketahui, bercerita merupakan suatu cara yang paling efektif untuk memberikan nasehat, pesan, pencerahan, dan motivasi kepada anak remaja. bercerita sebetulnya mirip dengan memberikan contoh nyata ke dalam imajinasi anak remaja. Dengan perasaan senang anak remaja akan lebih mudah menyerap dan memahami isi cerita yang disampaikan kepadanya. Pilihlah kisah atau cerita yang menarik bagi anak, sesuai dengan umurnya, dikemas dengan cara yang dapat menembus perasaan secara mudah, dan doronglah ia untuk melakukan kebaikan tersebut.

\section{b. Orang Tua Mengangap Anaknya Sebagai Teman}

Anak berusia pada 16 tahun keatas yaitu menginjak pada masa remaja, seorang anak akan memerlukan sahabat, karena meraka sudah mempunyai naluri seperti orang dewasa. Orang tualah disini dapat menjadi sahabat anak tersebut agar anak lebih merasa dekat dengan orang tua, dan apabila ada masalah yang ingin dinsampaikan bisa langsung ke orang tua. Orang tua akan berusaha menberikan jalan terbaik kerana orang tua tidak mungkin mau melihat anaknya sengsara. Peran orang tua pada masa ini hendaknya memberikan kebebasan untuk bertindak dan menentukan sikap agar hidupnya tidak tergantung dari orang tua jika seandainya mereka berbuat kekeliruan orang tua hanya menasehati dan meluruskan kearah jalan yang benar (Suardi, 2006 :49)

Orang tua harus menjadi pendengar yangaktifapabilaanakinginmenyampaikan suatu hal atau masalah yang di alaminya, kemampuan orang tua untuk menguraikan perasaan anak dengan tepat, jadi orang 
tua mengerti perasaan anak mereka yang dikirim anak lewat bahasa verbal maupun nonverbalnya. Keuntungan dari mendengar aktif, anatara lain: mendorong terjadinya katarasis; menolong anak tidak takut terhadap perasaan (positif-negatif); mengembangkan hubungan yang sangat dengan orang tua; memudahkan anak memecahkan masalahnya; meningkatkan kemampuan anak untuk mendengar pendapat orang tua meningkatkan tanggung jawab anak.

\section{KESIMPULAN}

Implementasi pendidikan informal Hindu dalam menjaga pola komunikasi remaja pada pergaulan sehari-hari sebagai alat untuk melakukan pembinaan atau pendidikan untuk anak remaja agar terarah ke hal-hal yang baik dan tidak terjerumus kearah yang bisa menyebabkan masa depan anak itu suram, serta dapat membuat diri anak itu mempunyai arah untuk meraih masa depan yng lebih baik. Orang tua harus menyempatkan waktu kepada anaknya untuk dapat ngobrol-ngobrol sambil memberikan pendidikan terhadap anak remajanya dengang maksud agar komunikasi dengan anak tidak terputus. Orang tua menasehati anaknya dengan cara bahasa yang membuat anak itu senang dan tertarik untuk mendengar nasehat orang tua selanjutnya. Pada anak berusia 16 tahun keatas yaitu menginjak pada masa remaja, seorang anak akan memerlukan sahabat, karena meraka sudah mempunyai naluri seperti orang dewasa maka itu orang tua lah disni dapat menjadi sahabat anak tersebut agar anak lebih merasa dekat dengan orang tua.

\section{DAFTAR PUSTAKA}

Adi wiratmaja, G. A. 1998. Etika Tata Susila Hindu Dharma. Denpasar. Parisada Hindu Dharma Indonesia Pusat.

Ali Mohamad, Mohamad Asori. 2004. Psikoliogi Remaja Perkembangan Perserta Bidik, Jakarta: Bumi Aksara

Daradjat. Zakiah. 1982. Pendidikan Agama dalam Pembinaan Mental. Jakarta :NV Bulan Bintang.

Daunes Schaltz, 1991. Psikoligi Pertumbuhan, Yogyakarta: Kanisus.

Gurungan, W.A, 2002. Psikologi Sosial. Bandung. Refika Aditama.

Hasim, Umar. 1983. Cara Mendidik Anak. Surabaya: Bina Ilmu

Harmoko,1988. Komunikasi sambung rasa. Jakarta: Pustaka Sinar Harapan.

Iqbal, Hasan, 2002. Metode Penelitian dan Aplikasinya. Jakarta: Ghalia Indonesia.

Kajeng, I Nyoman, dkk. 2005. Sarascamuscaya dengan Teks Bhs. Sansekerta dan Jawa Kuno. Surabaya : Paramita.

Rumini, Sri, 2004. Perkembangan Anak dan Remaja, Jakarta : Rineka Cipta

Sudarsana, I. K. (2018). Peranan Keluarga Hindu Dalam Mengantisipasi Perpindahan Agama.

Sudarsana, I. K. (2018, January). Membina Kerukunan Antar Siswa Di Sekolah Melalui Penanaman Pendidikan Budi Pekerti Berbasis Kearifan Lokal. In 

PROSIDING SEMINAR NASIONAL KEARIFAN LOKAL INDONESIA UNTUK PEMBANGUNAN KARAKTER UNIVERSAL 2015 (pp. 242-250).

Sugiharta, I. P. S. O., \& Sudarsana, I. K. (2017). Hypnotic Learning Characteristics On Sisya Brahmakunta Community In Denpasar. Vidyottama Sanatana: International Journal of Hindu Science and Religious Studies, 1(2), 132-145.

Wiana, I Ketut. 1997. Beragama Bukan Hanya di Pura (Agama Hindu Sebagai Tuntunan Hidup). Denpasar : Yayasan Dharma Naradha.

Wisarja, I. K., \& Sudarsana, I. K. (2017). Praksis Pendidikan Menurut Habermas (Rekonstruksi Teori Evolusi Sosial Melalui Proses Belajar Masyarakat). Indonesian Journal of Educational Research, 2(1), 18-26.

Wisarja, I. K., \& Sudarsana, I. K. (2017). REFLEKSI KRITIS IDEOLOGI PENDIDIKAN KONSERVATISME DAN LIBRALISME MENUJU PARADIGMA BARU PENDIDIKAN. Journal of Education Research and Evaluation, 1(4), 283-291. 